\title{
Productive Waqf, Economic Empowerment, and Public Welfare: Evidence from Benefit Recipients at Daarut Tauhiid Waqf Institution
}

\author{
Wildan Munawar, M. Arief Mufraini \\ Universitas Djuanda Bogor, Indonesia \\ UIN Syarif Hidayatullah Jakarta, Indonesia \\ wildan.munawar@unida.ac.id,ariefmufraini@uinjkt.ac.id
}

\begin{abstract}
This study aimed to determine the effect of productive waqf management on public welfare with economic empowerment as an intervening variable. The research method used quantitative research, and the data collection used a closed-ended questionnaire. The sampling was selected based on the purposive sampling technique by determining certain criteria and objectives. The data analysis technique used Partial Least Square (PLS) with the PLS 3 smart application. The results of this study concluded that productive waqf management had a positive and significant effect on public welfare with economic empowerment as an intervening variable. The better the management of productive waqf carried out by the waqf institution, the more indirectly it would improve the public welfare with good economic empowerment. The good of productive waqf management can be used as a benchmark for waqf institutions in managing waqf. This was because past experience and history have proven that well-managed waqf improved public welfare through economic empowerment carried out consistently. However, not only through the cultivation of worship and Islamic character but also supported by skills and training in business improvement, mentoring, and monitoring of business operations, as well as providing business and marketing capital.
\end{abstract}

Keywords:Productive Waqf Management, Economic Empowerment, Public Welfare

Permalink/DOI: https://doi.org/10.18326/infsl3.v15i1.1-24 


\section{Introduction}

Productive waqf plays a very big role and influence in the history of human life, not only limited to worship interests but can affect and function in various things, including educational, social, and economic development (Bakhri, 2016; Zuki, 2012; Kasdi, 2016). In the education field, the results of waqf management can be used to finance educational operations, infrastructure maintenance and provide scholarships (Kasdi, 2016). Meanwhile, from the economic side, the results of productive waqf can be used to provide capital for small and medium enterprises through sharia-based microfinancing, productive and consumptive financing, and other financing and investment financing in the capital market (Islam, 2015). The benefits of productive waqf are obtained from land waqf, building/property waqf, cash waqf, investment waqf, and managed stock waqf (Puspitasari, 2017; Kahf \& Mohomed, 2017).

The development of productive waqf from the various types of waqf has very little benefit felt by the community. This is because there are still many nàzirs who traditionally apply waqf management, the lack of managerial skills possessed by nàzirs, and the understanding of nàzirs who still adhere to the principle of immortality and cannot be changed, thus causing nàzir to be afraid to develop and produce waqf assets. Fauzia (2018), Koto \& Saputra (2016), and Megawati (2014) also explained that the cause of traditional productive waqf management is motivated by several factors, namely the understanding of nàzir, which still adheres to the interpretation of traditional Syafi'i fiqh, the management of productive waqf assets is more principled on a tradition of rigid business management and lack of innovation, the nàzir profession is considered a voluntary side job, and the nàzirs lack of competence in managing and developing waqf assets.

As one of the institutions that collect and manage waqf funds in Indonesia, Daarut Tauhiid waqf institution has managed waqf professionally and in a productive direction. The collection and management of Daarut Tauhiid waqf funds until the end of December 2018 has raised approximately IDR.15 billion funds. Then, the management of these funds is distributed according to the allocation of waqf, including mosque waqf, dormitory waqf, 
Al-Qur'an waqf, and general waqf. The following is data from the management of waqf funds at the Daarut Tauhiid waqf institution.

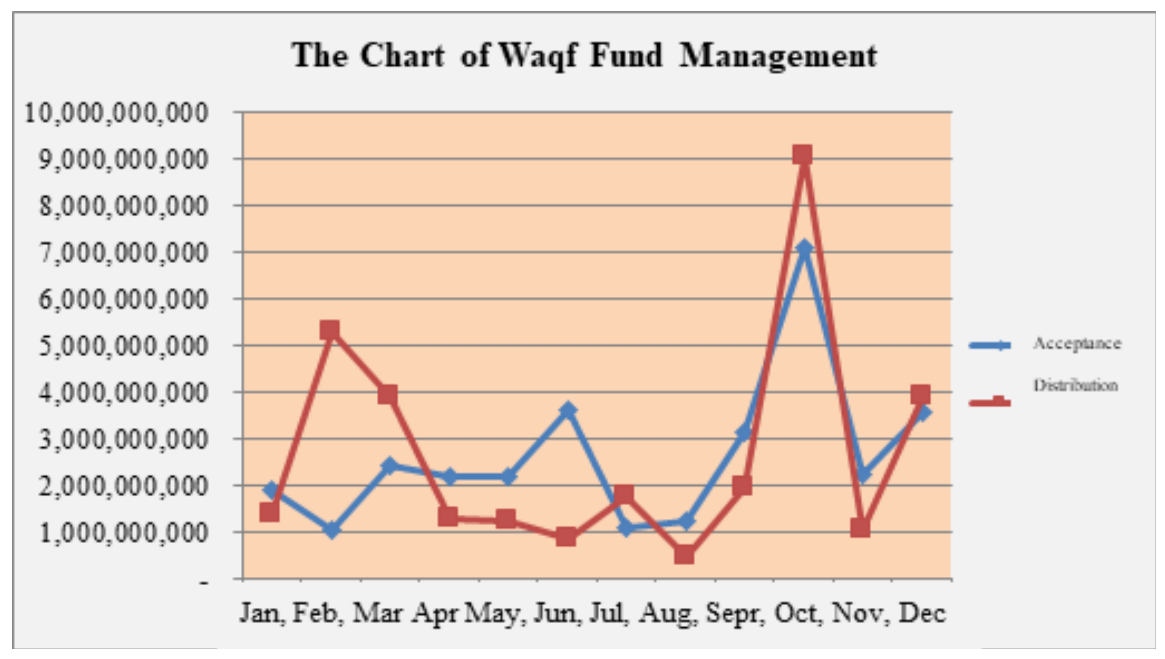

Figure 1. Management of the Daarut Tauhiid Waqf Funds Source: Financial Report of Daarut Tauhiid, 2019

Figure 1 above shows that the management of waqf funds from the Daarut Tauhiid waqf institution fluctuates every month, both in terms of collection and distribution. The largest collection of waqf funds occurs in October, while the lowest occurs in February and July. The amount of acceptance of the collection of waqf funds is due to the presence of waqf funds originating from Muslims in Australia to build the First Indonesian Mosque in Perth, Australia. In addition, the Daarut Tauhiid 3 in 1 waqf development program consists of the DT Batam mosque, Al Hadi mosque at DT Serua Tangerang, and Rahmatan Lil Alamin mosque at DT Lubuk Linggau also encourage people to do waqf. The amount of revenue obtained generally comes from waqf funds for mosques. Likewise, the distribution of waqf funds is generally more towards the construction of mosques. While the receipt of funds from productive waqf is obtained from the management and development of waqf assets which include productive waqf shops, Daarul Hajj building, Dome Central 5 building, Daarul Jannah Cottage and Mice, Daarut Tauhiid Super Mini Market (SMM), ATMs around Islamic boarding schools, radio MQFM, Belia Food canteen, and other productive waqf assets. The results of this management are then distributed to 
the community around the Daarut Tauhiid waqf institution, both directly and indirectly.

The management of Daarut Tauhiid's waqf assets has provided many benefits and great impacts for the community. One of the benefits to economic life is the increase in people's income through the benefits obtained from utilizing the waqf assets of the Belia Food canteen, shops (bazaars), and other waqf assets around the Daarut Tauhiid Islamic Boarding School. People who use waqf assets are also accustomed to carrying out their prayer obligations on time and following religious studies carried out by Daarut Tauhiid. These forms of activity can indirectly be part of empowering the community that receives the benefits of waqf, which will support the improvement of spiritual welfare. Therefore, the professional management of productive waqf can support the improvement of public welfare both materially and spiritually. The nàzir can also focus more on collecting and managing waqf assets to develop and provide greater benefits to the community.

\section{Literature Review}

\section{Productive Waqf Management}

Management is a necessity that must be done in managing waqf. It aims to run in accordance with the goals and objectives that have been set. Waqf management is used to regulate every process of waqf management, starting from collecting waqf funds, distributing them to each waqf program, reporting the waqf funds that have been obtained, and maintaining good relations with all waqf stakeholders, both nàzir, waqif, waqf board, government, as well as community (Rozalinda, 2015:73). However, an important element in waqf management that must be possessed is the subject of the perpetrator, namely nàzir and the object of action, which includes the assets being managed, the cash waqf funds collected, the waqf program carried out, and the reporting of each collection and distribution of waqf.

Iman and Muhammad in Khamis \& Salleh (2018) explained that waqf management which an institution runs requires at least three of the most basic resources, namely nàzir, money, and property or assets. A competent and professional nàzir is needed in waqf institutions and is even a key factor in the success of waqf management (Rozalinda, 2015: 51). The professional nàzir also needs to be equipped with a strong Islamic character to produce 
a more efficient, accountable, and transparent waqf management, even though it lacks accounting information systems and some of its educated personnel (Ihsan \& Ibrahim, 2011). According to Djunaidi et al. (2005), professional nàzir is measured based on the parameters of the application of the Prophets character and traits, namely trustworthiness, honesty, intelligence, and transparency.

The productive waqf management carried out by nàzir is supported by the implementation of a strong Islamic character and must also be able to manage assets and report the finances of the waqf funds properly. The management of waqf assets in a modern and productive manner will improve the economy and public welfare. If waqf assets are not productive, the benefits of the value of social worship will disappear (Subhan, 2018). According to Priyaman (2019), the management of waqf assets will be able to play a socio-economic role if it refers to three things, namely the need for a paradigm of using waqf assets in the economy, increasing the capacity of nàzir in entrepreneurship, and extracting cash waqf. As for financial reporting, delivery must be carried out in a transparent and accountable manner. Financial reporting transparency is one of the modern management principles applied by the Prophet through the nature of tabligh, emphasizing the willingness and ability to convey good and correct information. Meanwhile, the accountability of waqf institutions will have an impact on the strengthening of social legitimacy and increased community trust and support (Yuliani \& Bustaman, 2017; Budiman, 2011).

\section{Economic and Waqf Empowerment}

Economic empowerment is closely related to the professional management of productive waqf. The productive waqf management will generate many benefits for the community's economic empowerment (Hasanah, 2015). However, economic empowerment can also be done through development from zakat, infaq, and shadaqah funds (Bahjatulloh, 2016). In order to realize economic empowerment, it requires the role of entrepreneurs who can create innovations in economic activities, such as production efficiency, market expansion, and others. The readiness of the community to become entrepreneurs is also an effort in economic empowerment accompanied by mentoring or coaching to increase community knowledge and skills in business (Hutomo, 2000; Muttaqin, 2011).

The process of economic empowerment can also be said to be 
a business incubator process that becomes a medium for budding entrepreneurs to realize and develop their business. However, before being given economic empowerment, firstly, the character of faith is instilled and built to be mentally and spiritually empowered. If the mental spirituality has been constructed successfully, then the development of aspects of economic independence with increased capacity is in accordance with the needs of the business (Ryandono \& Hazami, 2016).

\section{Public Welfare}

Welfare in Islam is measured not only from the material aspect but also spiritual welfare. Broadly speaking, public welfare includes three things: the fulfillment of human needs for religion, including worship and self-worship to Allah SWT, self and fellow humans, including family and the surrounding environment. The form of servitude is done by carrying out worship according to the guidelines prescribed by Allah SWT whenever and wherever, adhering to Islamic teachings, and not violating sharia, including in seeking fortune. This implemented Islamic teaching value system is the basis of welfare which is the commander in the economic life of a nation (Nurkhalis, 2015; Sodiq, 2015; Beik \& Arsyianti, 2016). The need for oneself can be in the form of fulfilling material or physical needs, moral, psychological, and intellectual needs. The material or physical needs can be needed for food, drink, and shelter. The need for the environment is related to the fulfillment of the social conditions that surround it. An environment maintained, safe, comfortable, and peaceful is a condition expected by everyone. This is because if there are various kinds of crimes in the community, it will endanger people's lives and indicate that the community is not yet prosperous. They do not get calm, comfort and peace in life (Sodiq, 2015).

\section{Conceptual Framework}

Based on literature studies of various theoretical and empirical studies in previous research, there were two forms of research hypothesis tested in this study, namely; (1) there is an effect of productive waqf management on economic empowerment; and (2) there is an effect of economic empowerment on public welfare. The formulated research hypothesis was based on the conceptual framework that was the reference in this empirical research. The following is a conceptual framework that has been formulated. 


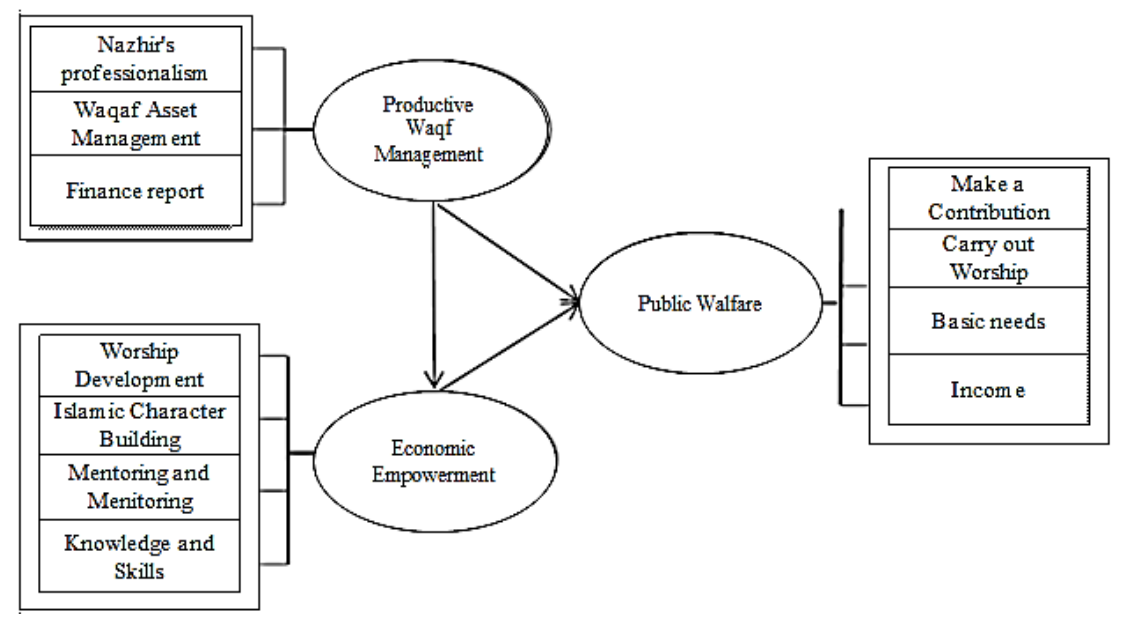

Figure 1. Research Conceptual Framework

Source: Authors Documentation

\section{Methods}

This study employed a quantitative approach to proving that empirically productive waqf management significantly affected public welfare through economic empowerment. The data collection technique used a closed questionnaire based on each latent variable's indicators. The research population was all people who got the benefit from waqf assets in Daarut Tauhiid. The sampling was determined based on the purposive sampling method, namely, based on certain criteria and objectives. The criteria determined were people who benefited from productive waqf assets around Daarut Tauhiid for at least more than one year. The samples obtained were 31 respondents from the population of waqf beneficiaries.

The data analysis technique used Partial Least Square (PLS) with the PLS 3 smart application. The Partial Least Square (PLS) method was used to test the manifest and latent variables using measurement models and structural models. The measurement model was used to test the validity and reliability, while the structural model was used to test the causality (hypothesis testing with predictive models) (M \& Abdillah, 2016:14). The stages in testing using PLS were making path diagrams, formulating measurement and structural equations, selecting input data and model estimates, identifying models, testing model suitability based on Average Variance Extracted (AVE) values, and testing hypotheses using the bootstrap resampling method. After 
obtaining the results from the bootstrapping process, the next was selecting path coefficients (Mean, Standard Deviation, t-values) and obtained inner loading values and t-values to assess the significance of the prediction model. If the T-statistics value was higher than the T-table value, it means that the hypothesis was supported. The T-table value with a confidence level of 95\% (5\% alpha) for the two-tailed hypothesis, the value was $>1.96$, while for the one-tailed hypothesis, the value was $>1.64$ ( $\mathrm{M} \&$ Abdillah), 2016).

\section{Results and Discussion}

Research Hypothesis Testing

The research hypotheses testing that has been formulated was using the measurement model or the outer model and the structural model or inner reflective construct model. The hypothesis testing with the measurement model was used to verify the manifest variables (indicators) and latent variables compiled. After verification, these variables were tested using a structural model to predict the relationships. The testing the outer model carried out included testing construct validity and construct reliability. The following are the results of testing construct validity and construct reliability.

Table 1. The Summary of Computation Results for the Measurement Model Statistics (Outer Model)

\begin{tabular}{|c|c|c|c|c|c|}
\hline \multirow{2}{*}{ Construct } & \multirow{2}{*}{ Items } & \multicolumn{2}{|c|}{$\begin{array}{c}\text { Construct } \\
\text { Validity }\end{array}$} & \multicolumn{2}{|c|}{ Construct Reliability } \\
\hline & & Loadings & AVE & $\begin{array}{c}\text { Cronbach'S } \\
\text { Alpha }\end{array}$ & $\begin{array}{l}\text { Composite } \\
\text { Reliability }\end{array}$ \\
\hline \multirow[t]{4}{*}{ Public Welfare } & KM1 & 0.921 & \multirow{4}{*}{0.700} & \multirow{4}{*}{0,861} & \multirow{4}{*}{0.903} \\
\hline & KM2 & 0.836 & & & \\
\hline & KM3 & 0.769 & & & \\
\hline & KM4 & 0.814 & & & \\
\hline \multirow{3}{*}{$\begin{array}{l}\text { Productive } \\
\text { Waqf } \\
\text { Management }\end{array}$} & MWP1 & 0.894 & \multirow{3}{*}{0.595} & \multirow{3}{*}{0,616} & \multirow{3}{*}{0.807} \\
\hline & MWP2 & 0.507 & & & \\
\hline & MWP3 & 0.853 & & & \\
\hline \multirow{4}{*}{$\begin{array}{l}\text { Economic } \\
\text { Empowerment }\end{array}$} & PE1 & 0.702 & \multirow{4}{*}{0.571} & \multirow{4}{*}{0,747} & \multirow{4}{*}{0.841} \\
\hline & PE2 & 0.870 & & & \\
\hline & PE3 & 0.737 & & & \\
\hline & PE4 & 0.700 & & & \\
\hline
\end{tabular}

Source: Smart PLS Data Processing Results, 2019 
Description:

$\mathrm{KM}=$ Community Welfare; MWP = Productive Waqf Management; $\mathrm{PE}=$ Economic Empowerment

Table 1 shows the results of measuring the value of loadings factors for each item, AVE, Cronbach's alpha, and composite reliability. Regarding the factor loadings, based on Hair et al. (2010), the loadings of factor items that exceed the recommended value of 0.5 are considered significant and acceptable. Table 1 shows all items having a loadings factor of 0.5 or higher. In contrast, Cronbach's Alpha output results for the construct of welfare, waqf management, and economic empowerment have a value above 0.60. It means that the three constructs that have been tested have good reliability. The lowest Cronbach's Alpha value is 0.616 in the waqf management construct. Meanwhile, all tested constructs have a composite reliability value of more than 0.6 , indicating high internal consistency of the existing data. All constructs have a value ranging from 0.807 to 0.903 , which is considered acceptable. On the other hand, all constructs having an AVE greater than 0.5 satisfy convergent validity.

The constructed model that has been tested and meets all the criteria for the measurement model was then tested for the structural model (inner model) by analyzing the R-Square value, which was the Goodness-fit model test. The R-Square value was used to measure how much influence a certain independent latent variable had on the latent dependent variable. The following is the R-Square value obtained from the output using Smart PLS 3.

Table 2. R-Square

\begin{tabular}{lll}
\hline Construct & R-Square & R-Square Adjusted \\
\hline Public Walfare & 0.424 & 0.404 \\
\hline Economic & 0.428 & 0.408 \\
Empowerment & & \\
\hline
\end{tabular}

Source: Data Processing Results, 2019

Table 2 shows that the R-Square $\left(\mathrm{R}^{2}\right)$ value for the welfare construct is 0.404 , while the R-Square $\left(R^{2}\right)$ value for the economic empowerment construct is 0.408 . The table above shows that the $\mathrm{R}^{2}$ value is higher than 0.33 . Therefore, it can be said that the modeling 
formed in this study is categorized as a moderate model. In addition to the R-Square value, the PLS analysis can also see how strong the effect size model is. The value of the effect size model can be seen in the F Square table.

Table 3. F-Square

\begin{tabular}{llll}
\hline Konstruk & $\begin{array}{l}\text { Public } \\
\text { Walfare }\end{array}$ & $\begin{array}{l}\text { Productive Waqf } \\
\text { Management }\end{array}$ & $\begin{array}{l}\text { Economic } \\
\text { Empowerment }\end{array}$ \\
\hline Public Walfare & & & \\
\hline $\begin{array}{l}\text { Productive Waqf } \\
\text { Management }\end{array}$ & & $\mathbf{0 . 7 4 9}$ \\
\hline $\begin{array}{l}\text { Economic } \\
\text { Empowerment }\end{array}$ & $\mathbf{0 . 7 3 5}$ & & \\
\hline
\end{tabular}

Source: Data Processing Results, 2019

According to Ghazali (2014), an effect size is weak if it is below 0.15 and is said to be strong if it is above 0.35 . From the table above, it can be seen that the construct of Waqf Management for economic empowerment of 0.749 is considered strong. Meanwhile, the construct of economic empowerment for the welfare of 0.735 is considered strong. Therefore, it can be said that construct modeling in this study is categorized as a strong effect of the predictor latent variables at the structural level.

The second test in the inner model stage was to see the significance of the effect of the productive waqf management variable on public welfare, the effect of productive waqf management on economic empowerment, and the economic empowerment variable on welfare by looking at the value of the parameter coefficient (original sample) as follows:

Table 4. Path Coefficients

\begin{tabular}{lllllll}
\hline & & $\begin{array}{l}\text { Original } \\
\text { Sample }\end{array}$ & $\begin{array}{l}\text { Sample } \\
\text { Mean }\end{array}$ & $\begin{array}{l}\text { Standard } \\
\text { Deviation }\end{array}$ & $\begin{array}{l}\text { T } \\
\text { Statistics }\end{array}$ & $\begin{array}{l}\text { P } \\
\text { Values }\end{array}$ \\
\hline MWP & KM & 0.426 & 0.448 & 0.092 & 4.627 & 0.000 \\
\hline MWP & PE & 0.654 & 0.659 & 0.119 & 5.506 & 0.000 \\
\hline PE & KM & 0.651 & 0.681 & 0.073 & 8.910 & 0.000 \\
\hline
\end{tabular}

Source: Data Processing Results, 2019

Description: 
$\mathrm{KM}=$ Public Welfare; MWP = Productive Waqf Management;

$\mathrm{PE}=$ Economic Empowerment

Table 4 shows the results of the path coefficient output to show the relationship and the significance of the effect of each variable by looking at the value of the parameter coefficient (original sample). The original sample size for the productive waqf management variable is 0.426 , which means that there is an effect between productive waqf management on welfare. These results can be interpreted that productive waqf management affects welfare with a t-statistic value of 4.627 greater than t-table 1.96 (4.627> 1.96). While the original sample size for the waqf management variable is 0.654 , the effect of waqf management on empowerment. These results can be interpreted that waqf management has an effect on empowerment with a t-statistic value of 5.506 greater than the t-table 1.96 (5.506> 1.96).

The size of the original sample for the economic empowerment variable is 0.651, which means an effect between economic empowerment on welfare. These results can be interpreted that the greater the institution's economic empowerment, the greater the public welfare will be with a t-statistic value of 8.910 greater than the t-table 1.96 ( $8.910>1.96)$. Based on the results of the tests carried out, it is found that the productive waqf management variable has an effect on the welfare and economic empowerment with a percentage of $42.6 \%$ and $65.4 \%$, respectively. The economic empowerment variable affects the welfare of the community with a percentage of $65.1 \%$.

\section{The Effect of Productive Waqf Management on Economic} Empowerment at Daarut Taubiid Waqf Institution

Based on the tests carried out on the structural model through the Goodness-fit model test using the Smart PLS 3 software, it was found that the productive waqf management described through the dimensions of nàzir professionalism, asset management, and waqf reporting indirectly affected the public welfare through economic empowerment with R-Square value of 0.408 . This means that the management of productive waqf managed properly will affect the economic empowerment of the community by $40.8 \%$, while the remaining $59.2 \%$ is affected by other factors besides productive 
waqf management.

The findings of this study indicated that productive waqf management affects public welfare through economic empowerment. This proves that productive waqf management affects economic empowerment. This study is in line with Cizacka's (1998) statement that throughout Islamic history, the waqf system implemented has provided all community services without imposing state fees. In addition, the modernization of the waqf system succeeds in implying a significant reduction in government spending and all associated benefits, including streamlining of the state sector and reduction and even elimination of usury.

This study is in line with Rozalinda (2016), who mentioned that the management of productive waqf has a positive effect on the community's economic empowerment by building facilities for economic and educational needs such as shops, tutoring buildings, and rented houses. This economic empowerment is shown by the large number of people who take advantage of the waqf manager's business facilities so that people can do business in strategic places. Thus, the community will get a large profit, their trade turnover will increase, and their economic welfare will increase. The form of economic empowerment that occurred in West Sumatra is only providing business facilities or facilities that generally used the ijarah (lease) instrument. The use of leasing instruments is one of the low-risk investments, and the return on investment is certain. The asset owner only thinks about the cost of maintenance in anticipation of depreciating the asset's value. Meanwhile, the lessee,s business activities do not affect the owner of the asset. Economic empowerment has not been in the form of providing working capital and entrepreneurship assistance. The provision of working capital, which generally uses a profit-sharing scheme, is vulnerable to uncertain risks and returns. If there is a loss, then the owner of the capital and the manager shall jointly bear the loss. From the advantages of the rental system, the manager of the waqf assets prefers the ijarah (lease) instrument to the profit-sharing instrument.

This also happens to Daarut Tauhiid Waqf Institution. The 
economic empowerment carried out is still in the form of managing productive waqf assets that can then be used by the surrounding community using a rental system pattern. The manager of waqf Daarut Tauhiid has not carried out economic empowerment in the form of providing capital, business assistance, strengthening marketing for running businesses, strengthening income generation, and obtaining information that can support business sustainability. Currently, the empowerment carried out by the Daarut Tauhiid Waqf institution is still in the form of fostering worship and forming Islamic character through the implementation of the culture of closing shops or business premises 15 minutes before prayer time arrives. The formation of Islamic character is carried out in the form of studies routinely carried out by the Daarut Tauhiid, including the study of ma'rifatullah and the book of Al-Hikam. These studies can be used as an empowerment process in the spiritual aspect that will guide, guide, direct, and guide decisions in life (Huda, 2019). Although not directly programmed by the Daarut Tauhiid waqf institution, Aa Gym as the leader of the Daarut Tauhiid Islamic Boarding School plays a role in cultivating Islamic character in its congregation, including people who rent productive waqf assets.

This study is also in line with Yusuf (2017), who showed that the management of productive waqf at Al-Mubarak Islamic Boarding School, Sibulue District, Bone Regency, has a role in community economic empowerment. The management of productive waqf by the Al-Mubarak Islamic Boarding School is able to empower the community's economy by providing loan facilities to increase community businesses. The loan facility is not provided directly in cash but rather in the form of goods used in agriculture. Because most people who receive these loans are farmers, the form of the loan is in the form of purchasing goods for harvesting needs. The farmers pay for the loan after the harvest arrived. In addition to loan facilities, Al-Mubarak Islamic Boarding School also provides organic fertilizers that farmers can use for farming for free. The farmers can use organic fertilizer as a means of farming to reduce the operational costs that have to be incurred in farming. The management of waqf carried out by the Al-Mubarak Islamic Boarding School provides direct benefits in the economic sector, especially in agriculture. The 
results of this study are in line with Setiawan (2016), who concludes that the management of waqf for community empowerment can provide direct benefits in the economic and social fields.

This study also supports Alhifni et al., (2017) result, which explained that waqf is an instrument of community empowerment at the Daarut Tauhiid Islamic Boarding School. This community empowerment is shown by the development of two sectors, namely education and economy. From the economic sector, Daarut Tauhiid has built many productive waqf assets that can be utilized by the surrounding community, such as the Super Market Mini (SMM), Productive Waqf Bazaar Shops, stalls around Islamic boarding schools, canteens, food courts, and other assets that can be used in the form of a lease. A large number of productive waqf assets require professional management so that the benefits of waqf can continue. Therefore, the results of this study support empirically that the better the management of waqf is carried out, the more it will increase the community's economic empowerment. The ongoing management of waqf is carried out by nàzirs who are professional in managing waqf assets, so transparency and accountability in reporting can also be felt and known by the public, both waqif, users, government, and other parties related to waqf. This study also strengthens the conclusions of Muslim (2017) and Hamzah (2016), which illustrated that the management of waqf to strengthen the economy of the ummah requires professional management so that competent nàzirs are needed to handle it because the position of nàzir is directly related to the success of waqf management.

This study is also in line with Rofa'i, Burhan, and Multifiah (2016) that productive waqf managed by professional nàzir affects improving people,s welfare, including creating new jobs used by the community, which has an impact on increasing income. According to them, the public welfare in the form of the VIP room of the Malang Islamic Hospital provides a choice for people who want a comfortable, clean, and fast room. In addition, the presence of a minimarket can provide comfort in meeting the needs of daily life because the place is easily accessible and the price is quite low compared to others. The results of productive waqf management for VIP rooms and minimarkets are distributed directly to the community 
in the form of community guidance and empowerment through da'wah programs such as grants/incentives for diniyah teachers, incentives for imams, mosque operational costs, and cash for the local environment. Agusci (2019) also found that waqf managed productively has a positive impact on improving the economic standard of life of the community, is able to open new jobs, and create new entrepreneurs in Indonesia.

The Effect of Economic Empowerment on Public Welfare in the Daarut Taubiid Waqf Institution

Based on the tests carried out on the structural model through the Goodness-fit model test using the Smart PLS 3 software, the results show that economic empowerment directly affects the public welfare with an R-Square value of 0.404 . It can be interpreted that the construct of economic empowerment as measured by religious guidance, Islamic character formation, mentoring and monitoring, as well as knowledge and skills, has a significant effect on public welfare by $40.4 \%$, while the remaining $59.6 \%$ is affected by other variables which are not examined in this study.

The findings of this study indicated that economic empowerment has a positive and significant effect on public welfare. In Islam, the expected welfare is not always worldly related to material matters and welfare in enhancing Islamic spiritual values both for individuals and society (Zarqa, 1981). This statement is confirmed by the results of a study by Beik and Pratama (2015), which stated that welfare is not only measured by material indicators alone, but there are non-material (spiritual) indicators such as prayer, fasting, zakat, and infaq. Therefore, a prosperous Muslim does not only increase his income but also increases in his spiritual aspect. The spiritual aspects felt by the community are more devoted to the implementation of the five daily prayers, always attend recitation once a week. When they are busy, they do not leave a prayer. This can also be seen in the Daarut Tauhiid environment, which obliges every seller when the prayer time comes, all trading activities are suspended temporarily. Likewise, with the recitation activity, Daarut Tauhiid conducts routine studies at the Daarut Tauhiid Mosque once a week. With this routine review, the sellers can follow the study conducted by Daarut Tauhiid. In addition to income and an 
increase in the spiritual aspect of worship, welfare is also measured by indicators of making a contribution and fulfilling basic needs.

The donation assessed in this study contributes to social activities by setting aside donations when making a profit. In addition, the beneficiaries also set aside their funds to be given to orphans and underprivileged children once a year. This form of regular material donation is an indicator that includes the Keluarga Sejahtera III Plus (KS-III Plus) as measured by the National Population and Family Planning Board (BKKBN).

The form of distribution of assets in relation to giving donations can be in the form of alms, grants, endowments, wills, and inheritance. However, the contribution of the beneficiaries is mostly made in the form of alms. As for basic needs, the beneficiary communities who use these productive waqf assets have met their basic needs both from the needs of food, drinks, and clothing, and a house or a place to live. The amount of income obtained is in accordance with the results of observations and the percentage of beneficiaries which shows that 35\% have an income of more than IDR.2,500,000. The amount of income earned is still meeting the daily needs of the beneficiary community.

The results of this study are in line with Yatiningrum, Hendra, and Saifullah (2017). They stated that empowerment has a significant effect on the income of women traders in the informal sector in Leces District, Probolinggo Regency. This study also supports the results of Lalaun and Siahaya's (2015) study that empowerment programs have a significant effect and impact on public welfare. This is due to the presence of community skills and training in the empowerment program. Sulaiman, Chusmeru, and Masrukin (2018) also emphasized that economic empowerment is very important because it improves institutions, membership, finance, and agribusiness development of business groups. Economic empowerment in relation to waqf institutions really needs to be improved, both in terms of skills and training in the context of increasing resource capacity. According to Daulay (2016), one of the measures of community economic empowerment is creating and innovating. One way to increase creation and innovation is 
through the competencies of nàzirs through training organized by the institution. In addition, nàzir must also understand sharia rules for waqf investment, sharia principles in waqf investment, maintenance and renovation of waqf assets (Ilyas, 2017).

The above study results have proven that the management of productive waqf managed properly will improve public welfare through economic empowerment. Economic empowerment is meant by developing micro-businesses by using productive waqf assets at a more affordable rental cost. However, this study did not agree with Kuran, who stated that waqf actors apply Islamic principles as ambiguous guidelines for achieving justice. The achievement of substantive justice becomes a mere procedural issue. According to him, this is an illusion (Aprilianto, 2018). Kuran (2001) asserted that in the 19th century, the establishment of inspired European cities marked the official rejection of the waqf system. Some of these claims arise because Islamic law requires waqf managers or nàzir to comply with the provisions of the founder of the waqf, so that it does not have the flexibility to compete with rapidly changing economic conditions is not a suitable system for a medieval economy. This makes the waqf system proven to be incompatible with the economic dynamics of the industrial era. In addition, Kuran also argued that Islamic economists disagree with Islamic principles, and one author is inconsistent with another. Kuran concluded that Islamic economists had not created a strategy to fight the injustices they find in the existing social order, including waqf. However, on the other hand, Kuran did not highlight that waqf has played a very important role in developing social, economic, and cultural activities. Criticism of the opinion of waqf, Kuran said that Muslims should reconstruct the management system of waqf management, so that waqf assets can be used as an instrument to stimulate the economic activity of the ummah, not only motivated by certain motives or getting personal interests (maslahah khasshah) by using waqf means (Aprilianto, 2018). 


\section{Conclusion}

This study proves that productive waqf management, as reflected by the professionalism of nàzir, waqf asset management, and financial reporting, has a positive and significant effect on public welfare through economic empowerment. Based on the results of statistical tests using Smart PLS 3, it is found that the independent variable of productive waqf management has a positive and significant effect on public welfare through economic empowerment as an intervening variable. This further strengthens the views of productive waqf management experts such as Murat Cizacka dan Monzer Kahf, as well as the research results of Rozalinda, Hardiyanti Yusuf, Anas Alhifni, Nurul Huda, Musclih Ansori, and Rully Trihantana, Muslihun Muslim, Zulfadli Hamzah, and others, stated that productive waqf managed by professional management plays a very important role and affects the public welfare by means of economic empowerment. However, this study did not agree with Timur Kuran, which stated that the waqf system applied by using Islamic principles causes ambiguity in achieving substantive justice.

The results of this study are expected to contribute to the improvement of management carried out by the Daarut Tauhiid waqf institution in particular, and the productive waqf management of other waqf institutions in managing waqf so that it plays a greater role in improving public welfare through economic empowerment. It is hoped that other waqf institutions in carrying out economic empowerment, the community will not only use productive waqf assets but also be given special programs in the context of business improvements such as skills in marketing, business innovation, training, and other special skills that are not owned by the community. In addition, in the use of shop houses or business premises that are part of the waqf assets, not only use a lease agreement (ijarah) but can also use a profit-sharing contract that does not have to spend funds. The user community acts as the mudarib or manager of the waqf assets, while the waqf institution becomes the shabibul mal or the owner of the funds of the waqf assets. The provisions for the profit-sharing ratio of the contract can be determined with the agreement of both parties between the community and the waqf institution. From the side of waqf beneficiaries, waqf institutions can 
determine and ensure the real economic condition of the beneficiary communities to be empowered. It is intended that the economic empowerment programs carried out by waqf institutions can be beneficial and have a direct impact on improving the economy and public welfare, both material and spiritual welfare. 


\section{References}

Agusci, B. I. (2019). Urgensi Pengelolaan Wakaf Produktif Dalam Pembangunan Ekonomi Dan Pemberdayaan Masyarakat. $M i-$ sykat Al-Anwar: Jurnal Kajian Islam dan masyarakat, 30(1), 46.

Alhifni, A., et.al. (2017). Waqf an Instrument of Community Empowerment in Islamic Boarding School Daarut Tauhiid in Indonesia. Journal of Islamic Economics, Banking and Finance, 13(2), 76-88.

Aprilianto, D. (2018). Dilema Wakaf Timur Kuran Perspektif Maqashid syariah. Jurnal Ekonomi Syariah, 2(2), 206-216.

Bahjatulloh, Q. M. (2016). Pengembangan Pemberdayaan Ekonomi Masyarakat Melalui Kegiatan Filantropi (Studi Kasus Lembaga Tazakka DIII Perbankan Syariah IAIN Salatiga). INFERENSI: Jurnal Penelitian Sosial Keagamaan, 10(2), 473-494.

Bakhri, A. (2016). Peranan Wakaf Produktif Pemuda Muhammadiyah untuk Kesejahteraan Warga Desa Longkeyang, Bodeh, Pemalang. Indonesian Journal of Islamic Literature and Muslim Society, 1(2), 199-214.

Beik, I. S., \& Arsyianti, L. D. (2016). Ekonomi Pembangunan Syariah. Jakarta: Rajawali Pers.

Beik, I. S., \& Pratama, C. (2015). Analisis Pengaruh Zakat Terhadap Penurunan Tingkat Kemiskinan dan Peningkatan Kesejahteraan Mustahik Berdasarkan Model CIBEST. In F. R. III, Kumpulan Hasil Riset Terbaik. Depok: Otoritas Jasa Keuangan-IAEIUI.

Budiman, A. A. (2011). Akuntabilitas Pengelola Lembaga Wakaf. Jurnal Walisongo, 19(1), 75-102.

Cizacka, M. (1998). Awqaf in History and Its Implications for Modern Islamic Economies. Journal of Islamic Economic Studies, 6(1), 43-70.

Daulay, R. (2016). Pengembangan Usaha Mikro Untuk Pemberdayaan Ekonomi Umat Islam Di Kota Medan. Jurnal MIQOT, $X L(1), 44-65$. 
Djunaidi, A. ,et. al. (2005). Paradigma Baru Wakaf di Indonesia. Jakarta: Direktorat Wakaf.

Fauzia, A. (2018). Waqf Making and Commercial Cemeteries: Religious Circulation and Commodification of the Economy of Giving: Waqf Making and Commercial Cemeteries. The Muslim World, 108(4), 676-701, http://doi.wiley.com/10.1111/ muwo.12269

Ghazali, I. (2014). Structural Equation Modelling: Metode Alternatif dengan Partial Least Square. Semarang: Badan Penerbit Universitas Diponegoro.

Hadyantari, F. A. (2018). Pemberdayaan Wakaf Produktif: Upaya Strategis untuk Kesejahteraan Ekonomi Masyarakat. Jurnal Middle East and Islamic Studies, 6(1).

Hair, J., et.al. (2010). Multivariate Data Analysis. Upper Saddle River, NJ: Prentice Hall.

Hamzah, Z. (2016). Peran Nazir dalam Mengembangkan Wakaf Produktif. Jurnal Ekonomi, Manajemen dan Akuntansi, 26(1), 76-89.

Hasanah, U. (2015). Cash Waqf and People Economic Empowerment in Indonesia. Economics and Finance in Indonesia 59(2), 215-232, https://doi.org/10.7454/efi.v59i2.64.

Huda, I. (2019). Pemberdayaan Masyarakat Berbasis Multikultural di Majelis Taklim An Najach Magelang. INFERENSI: Jurnal Penelitian Sosial Keagamaan, 13(2), 253-278.

Hutomo, M. Y. (2000). Pemberdayaan Masyarakat dalam Bidang Ekonomi: Tinjauan Teoritik dan Implementasi. Yogyakarta: Adiyana Press.

Ihsan, H. \& Ibrahim, S. H. (2011). WAQF Accounting and Management in Indonesian WAQF Institutions: The Cases of Two WAQF Foundations. Humanomics, 27(4), 252-269, https:// doi.org/10.1108/08288661111181305

Ilyas, M. (2017). Profesional Nazhir Wakaf dalam Pemberdayaan Ekonomi. Jurnal A-Qadhaau Peradilan dan Hukum Keluarga 
Islam, 4(1), 71-94.

Islam, M. M. (2015). Cash-Waqf: New Financial Instrument for SMEs Development in Bangladesh. World Vision Research Journal, x(1), 111-120.

Kahf, M. \& Mohomed, A. N. (2017). Cash Waqf An Innovative Instrument of Personal Finance In Islamic Banking. Journal of Islamic Economics, Banking and Finance, 13(3), 13-29.

Kasdi, A. (2016). Pemberdayaan Wakaf Produktif untuk Pengembangan Pendidikan. Edukasia: Jurnal Penelitian Pendidikan Islam, 11(1), 159-179.

Khamis, S. R. \& Salleh, M. C. (2018). Study On The Efficiency of Cash Waqf Management In Malaysia. Journal of Islamic Monetary Economics and Finance, 4(1), 61-84, https://doi. org/10.21098/jimf.v4i1.732

Koto, A. \& Saputra, W. (2016). Wakaf Produktif di Negara Sekuler: Kasus Singapura dan Thailand. Jurnal Sosial Budaya, 13(2), 126-139.

Kuran, T. (2001). The Provision of Public Goods under Islamic Law: Origins, Impact, and Limitations of the Wakaf System. Blackwell Publishing on behalf of the Law and Society Association, 35(4), 841, https://doi.org/10.2307/3185418

Lalaun, A. \& Siahaya, A. (2015). Dampak Program Pemberdayaan Terhadap Kesejahteraan Masyarakat Di Kecamatan Yaru Kabupaten Maluku Tenggara Barat. Jurnal Administrasi Publik, $5(2), 85$.

M, Jogiyanto H., \& Abdillah, W. (2016). Konsep \& Aplikasi PLS (Partial Least Square) untuk Penelitian Empiris. Yogyakarta: BPFE.

Megawati, D. (2014). Pengelolaan dan Pengembangan Wakaf Produktif di Kota Pekanbaru. Jurnal Hukum Islam, 14(1), 104124.

Muslim, M. (2017). Peran Nazir Profesional dalam Pengelolaan Wakaf Guna Mendorong Pemberdayaan Ekonomi Umat di Indonesia. Iqtishaduna: Jurnal Ekonomi Syariah, 8(2), 37- 46. 
Muttaqin, R. (2011). Kemandirian dan Pemberdayaan Ekonomi Berbasis Pesantren (Studi atas Peran Pondok Pesantren Al-Ittifaq Kecamatan Rancabali Kabupaten Bandung terhadap Kemandirian Eknomi Santri dan Pemberdayaan Ekonomi Masyarakat Sekitarnya). JESI (Jurnal Ekonomi Syariah Indonesia), 1(2), 65-94.

Nurkhalis. (2015). Kesejahteraan Sosial di Indonesia Perspektif Ekonomi Islam. Akademika, 30(2), 243-260.

Priyaman, L, "Manajemen Aset Wakaf" diakses pada 29 September 2019 lihat https://bwi.or.id/index.php/en/publikasi/artike1/1195-manajemen-aset-wakaf.html

Puspitasari, A. W. (2017). Optimizing Productive Land Waqf Towards Farmers Prosperity. Journal of Indonesian Applied Economics, 6(1), 103-112.

Rofa'i, Y., Burhan, U., \& Multifiah. (2016). The Role of Productive Waqf for Public Welfare (Study Case of Nadzir Foundation in University of Islam Malang). International Journal of Social and Local Economic Governance (IJLEG), 2(2), 152-160.

Rozalinda. (2015). Manajemen Wakaf Produktif. Jakarta: Rajawali Pers.

Rozalinda. (2016). Management Waqf Produktif di Sumatera Barat. AWQAF: Jurnal Wakaf dan Ekonomi Islam, 9(2), 1-27.

Ryandono, M. N., \& Hazami, B. (2016). Peran dan Implementasi Waqaf Dalam Peningkatan Kesejahteraan Masyarakat . INFERENSI: Jurnal Penelitian Sosial Keagamaan, 10(1), 239-264.

Setiawan, E. (2016). Pengelolaan Wakaf Pondok Pesantren Al-Hikmah Sirampog Kabupaten Brebes. INFERENSI: Jurnal Penelitian Sosial Keagamaan, 10(2), 495-516.

Sodiq, A. (2015). Konsep Kesejahteraan dalam Islam. Equilibrium, $3(2), 380-405$.

Subhan, M. (2018). Kontekstualisasi dan Reposisi Fungsi Wakaf dalam Upaya Meningkatkan Kesejahteraan Umat. Jurnal Ekonomi Syariah 2(2), 168-184. 
Sulaiman, A. I., Chusmeru, \& Masrukin. (2018). Strategy of Cooperative Islamic Boarding School as Economic Empowerment Community. INFERENSI: Jurnal Penelitian Sosial Keagamaan, 12(1), 25-44.

Yatiningrum, A., Hendra, J., \& Saifullah. (2017). Analisis Pengaruh Pemberdayaan Wanita Pedagang Sektor Informal Terhadap Peningkatan Pendapatan Rumah Tangga. Jurnal Manajemen dan Kewirausahaan, 5(2), 55-63.

Yuliani, N. W. \& Bustaman. (2017). Akuntabilitas dan Transparansi Pengelolaan Aset Wakaf pada Baitul Mal Kota Banda Aceh. Jurnal Ilmiah Mahasiswa Ekonomi Akuntansi (JIMEKA), 2(4), 75-83.

Yusuf, H. (2017). Pengelolaan dan Pemanfaatan Wakaf Produktif dalam Pemberdayaan Ekonomi Masyarakat pada Pesantren Al-Mubarak Kec. Sibulue, Kabupaten Bone. Tesis Program Pascasarjana: UIN Alauddin Makassar.

Zarqa, A. (1981). Islamic Economic: An Approach to Human Islamic Welfare. In K. Ahmad, Studies in Islamic Economic (p. 13). United Kingdom: The Islamic Foundation.

Zuki, M. S. (2012). Waqf and Its Role In Socio-Economic Development. ISRA International Journal of Islamic Finance, 4(2), 173-178, https://doi.org/10.12816/0002755 